\title{
Nocturnal singing by diurnal birds in a temperate region of central Europe
}

\author{
Kinga Kułaga ${ }^{1}\left(\mathbb{D} \cdot\right.$ Michał Budka $^{1}$ (1)
}

Received: 1 February 2020 / Revised: 28 May 2020 / Accepted: 15 June 2020 / Published online: 23 June 2020

(c) The Author(s) 2020

\begin{abstract}
Most bird species sing by day, with two distinct peaks of vocal activity—around sunrise and sunset. However, even typically diurnal birds also sing during at night what is for them an atypical part of the day. To date, the mechanism and function(s) of such behaviour remain unclear across bird taxa. In our study we focused on night singing by diurnal birds in two different types of environments - forests and open areas in eastern Poland. We examined: (1) which diurnal species sing at night (defined as the period between astronomical dusk and dawn); (2) how intensively different species vocalise at night; and (3) whether the occurrence of nocturnal singing by diurnal birds depends on the type of environment. To do this, we used autonomous sound recorders to record soundscapes in 27 points located in open habitats and 27 points located in forests. At each location the recorder continuously collected data for an entire day during the breeding season, from one hour before dawn to 10 AM the next day. All night songs were classified to their species of origin via manual spectrogram scanning. We recorded 88 bird species in total (12 orders, 32 families), of which 24 species ( 7 orders, 15 families) sang at night. Night singing was observed significantly more often in open areas than in forests. The frequency and intensity of night singing was species-specific and ranged from occasional singing to regular and intense singing. We hypothesise that elevated light levels have a crucial influence on night singing, but that the effect of light may also be modified by environmental factors (e.g., predator pressure).
\end{abstract}

Keywords Nocturnal singing $\cdot$ Diurnal birds $\cdot$ Light effect $\cdot$ Song activity $\cdot$ Singing intensity

\section{Zusammenfassung}

\section{Nächtliches Singen tagaktiver Vögel in einer gemäßigten Region Mitteleuropas}

Die meisten Vogelarten singen bei Tag und zeigen dabei zwei ausgeprägte Spitzen der Gesangsaktivität: um Sonnenaufgang und -untergang herum. Es gibt jedoch auch ausgesprochen tagaktive Vögel, die nachts singen, also zu einer für sie untypischen Zeit. Bis heute sind der Mechanismus und die Funtion(en) dieses Verhaltens quer durch alle Vogelarten hinweg unklar. In unserer Untersuchung konzentrierten wir uns auf das nächtliche Singen tagaktiver Vögel in zwei unterschiedlichen Umgebungstypen: Wälder sowie offene Landschaften in Ost-Polen. Wir untersuchten: (1) welche tagaktiven Vogelarten singen nachts (definiert als die Zeit zwischen astronomischer Dämmerung und Morgengrauen); (2) wie intensiv ist die Gesangsaktivität der einzelnen Arten; (3) hängt das Auftreten nächtlichen Gesangs bei tagaktiven Vögeln von der Umgebung ab. Für die Untersuchung benutzten wir autonome Aufnahmegeräte zum Aufnehmen der Klanglandschaften an 27 Stellen in offenem Gelände sowie an 27 Punkten in Wäldern. An jeder dieser Stellen wurde vom jeweiligen Recorder während

Communicated by F. Bairlein.

Electronic supplementary material The online version of this article (https://doi.org/10.1007/s10336-020-01794-5) contains supplementary material, which is available to authorized users.

Kinga Kułaga

kinga.kulaga96@gmail.com

1 Department of Behavioural Ecology, Adam Mickiewicz University, Umultowska 89, 61-614 Poznań, Poland 
der Brutzeit kontinuierlich über einen ganzen Tag hinweg aufgezeichnet, von einer Stunde vor Abenddämmerung bis 10 Uhr vormittags am nächsten Tag. Alle nächtlichen Gesänge wurden manuell anhand ihres Spektrogramms einer Vogelart zugeordnet. Insgesamt erhielten wir Aufnahmen von 88 Vogelarten (12 Ordnungen, 32 Familien), von denen 24 Arten (7 Ordnungen, 15 Familien) während der Nacht sangen. Nächtlicher Gesang trat in offenen Landschaften signifikant häufiger als in Wäldern auf. Die Wiederholungshäufigkeit und Intensität des nächtlichen Gesangs hing von der Vogelart ab und reichte von gelegentlichem Singen bis hin zu intensivem Gesang. Wir vermuten, dass ein höherer Lichtpegel einen entscheidenden Einfluss auf das nächtliche Singen hat, dass aber der Effekt des Lichts auch von anderen Umweltfaktoren wie z. B. dem Druck durch Räuber modifiziert werden kann.

\section{Introduction}

Animals communicate by transferring information from a sender to a receiver using various types of signals: visual, auditory, chemical, or tactile (Bradbury and Vehrencamp 1998). One of the most developed forms of communication in birds is vocalisation, which can be divided into short, simple calls and long, usually complex songs (Catchpole and Slater 2003). Calls are produced intentionally by both sexes and are used for alerting others of danger, maintaining contact between individuals, or locating individuals in space (Catchpole and Slater 2003). Instead, songs, in temperate zones at least, are mostly produced by males and fulfil two basic functions: attracting a mate and defending a territory (Catchpole and Slater 2003). The term 'song' is taxonomically limited to songbirds (Oscines) but in a broader sense also includes non-oscine vocalisations that are intended to attract a partner or defend a territory (e.g., vocalisations of doves, nightjars, cuckoos; Kumar 2003).

Patterns of vocal activity among birds are strongly species-specific and vary both daily and seasonally (Ehnes et al. 2018). In most species, two peaks of vocal activity can be distinguished per day: around the sunrise (dawn chorus) and around the sunset (dusk chorus). During these periods of time, conditions are unfavourable for feeding because insects (the main food source of many birds) are less active due to the reduced air temperature (Krebs and Kacelnik 1983). In addition, the typical weather conditions found at dawn and dusk (lack of strong wind, high humidity) ensure effective sound transmission (Henwood and Fabrick 1979). However, some bird species (e.g., owls, nightjars, some rallidae) have developed anatomical and behavioural adaptations that enable them to be active under low lighting, even at night (Bowmaker and Martin 1978). Although most species demonstrate typical patterns of diurnal or nocturnal activity, it is well-documented that birds also vocalise during parts of the day that are atypical for them (La 2012). For example, Corncrake males (Crex crex) are normally vocally active at night, when they produce thousands of cracking calls, but can also be heard calling during the day (Tyler and Green 1996). On the other hand, many bird species which are considered to be typically active by day also sing at night, with the first reports of this behaviour coming from the nineteenth century (Edson 1893; Stevenson 1893). Most early reports were based on accidental observations in a few bird species of individuals singing after dusk (Pierce 1922; King 1966). Recent studies have shown, though, that night singing by diurnal birds may be more widespread than previously thought. For example, in North America 106 diurnal species, representing 22 of the 38 families of Passeriformes, have been classified as night singers (La 2012). The same study also reported that, of 126 bird species that sing by night, $52 \%$ do so regularly, $27 \%$ occasionally, and $21 \%$ rarely. These results indicate that nocturnal singing by diurnal birds, at least in North America, is quite common. Unfortunately, to the best of our knowledge, we still lack detailed and methodologically sound studies of this behaviour from other regions of the world, including Europe. Thus, we do not understand even basic aspects of this phenomenon, such as its commonness across bird taxa and the intensity of night singing by diurnal birds. Without this knowledge, it is difficult to explain the mechanism and function of such behaviour. An understanding of why some bird species vocalise during atypical parts of the day may help explain the evolution of acoustic signals in birds, which are under both interspecific as well as intraspecific evolutionary pressure.

One of the most important factors influencing nocturnal singing in diurnal birds seems to be lighting (Wright 1913). Bird species with very sensitive retinas and large pupils (e.g., thrushes) start singing earlier compared to birds that lack these features, such as the Common Chaffinch (Fringilla coelebs) or Eurasian Blue Tit (Cyanistes caeruleus; Thomas et al. 2002; McNeil et al. 2005). Their eyes are adapted to minimal light intensity, which is transformed into a nerve impulse, causing neurological changes in the brain that stimulate the organism to sing (Staicer et al. 1996). In the wild, both natural (e.g., moon, stars) and anthropogenic (cities, traffic) light sources may affect nocturnal vocalisation in diurnal birds (Da Silva and Kempenaers 2017). For example, the moon provides about 10 times more light when it is full than in the third quarter (Russell 1916). Studies on the White-browed Sparrow-Weaver (Plocepasser mahali) showed that males start singing earlier when the moon is full than during the other phases (York et al. 2014). Instead, the reverse pattern was observed in the White-throated Sparrow (Zonotrichia albicollis) and in the Ovenbird (Seiurus 
aurocapilla) - these species sang less intensively at night when the moon was full (Foote et al. 2018a). Similarly, artificial light generated by humans has a strong effect on birds' vocal activity (Da Silva et al 2016). For example, the American Robin (Turdus migratorius) shows high levels of nocturnal vocal activity in environments contaminated with anthropogenic light, but in unlit areas, the species does not vocalise after dark (Miller 2006). However, this behaviour may also be related to the impact of anthropogenic noise in urban areas, where birds start singing earlier to prevent their vocalisations from being masked by noise (Mendes et al. 2011). Thus, lighting seems to be only one factor affecting nocturnal vocalisation in diurnal birds. Furthermore, a comparison of results obtained from different studies or conducted on different species or locations suggests that light may have different effects on different species; these effects may also be modified by other factors, including phenotypic plasticity (Da Silva et al. 2016).

It is thought that the function of night singing is similar to that of daytime singing (mate attraction, rival deterrence; Kroodsma and Byers 1991; Catchpole and Slater 2003). However, it is still not understood why some diurnal bird species sing at night while others do not, and we lack answers to such basic questions as who (male or female) is the intended receiver of the night song or how this behaviour increases the reproductive success or survival rate of night singers. Like other activities undertaken by typically diurnal species under low lighting, nocturnal singing should be risky. Despite this, some species or individuals do vocalise at night, which presumably should somehow increase their fitness. At the most basic level, producing songs at night can increase the total number of songs produced by an individual in a single day, and it has been documented that a higher number of songs sung by a male can inform both males and females about his high quality (Mountjoy and Lemon 1991; Lampe and Espmark 1994). Therefore, the two main hypotheses for the function of nocturnal singing in diurnal birds are that it is used for mate attraction and/or territory defence. The first hypothesis argues that night singing attracts neighbouring females and thus increases the reproductive success of night singers through a higher rate of extra-pair copulation (Barclay et al. 1985). The second hypothesis assumes that night songs inform potential rivals about the occupation of the territory and the owner's readiness to defend it (Alessi 2010). Another alternative is that the function of nocturnal singing by males is to guard females (Amhrein et al. 2002). It could be that the singing male expects his mate to respond to his song, and to do this, the female must remain within the territory around the clock, which simultaneously decreases the female's chance for extra-pair copulation and guards the male's paternity (La 2012). Another function that has been proposed is reproductive stimulation. Singing by a male may contribute to the increased production of hormones, thus stimulating the production of a larger brood (Amhrein et al. 2002). Finally, night singing could also serve as a method for avoiding predation. Strong predator pressure during the day could decrease daytime vocal activity, but this could be compensated by higher nocturnal singing activity, and in this way increase the survival rate of night singers (Thomas et al. 2003). Taken together, the functions of night singing by diurnal birds seem to differ across taxa and probably also depend on environmental conditions or the status of an individual. However, to better understand this behaviour, methodologically sound studies are needed to examine how common and intensive night singing by diurnal birds is across bird taxa, various geographical regions, and habitat types.

In our study we focused on a few basic questions related to night singing by diurnal birds in central Europe: (1) Which diurnal species sing at night? (2) Of the species that sing at night, how intensive is night singing? (3) Is night singing by diurnal birds equally probable in two different habitat types-forest and open habitat? To answer these, we utilised autonomous sound recorders to collect soundscape recordings in 54 locations and manual spectrogram scanning to detect and identify each song produced at night to its species of origin.

\section{Materials and methods}

\section{Study area and point selection}

The study was conducted in the Upper Nurzec River Valley (Eastern Poland, coordinates: 52 $2^{\circ} 36^{\prime} \mathrm{N}, 23^{\circ} 14^{\prime} \mathrm{E}$ ). The vast majority of this area is covered by peatland meadows, situated in wide depressions along the Nurzec river. Arable fields are located mainly on the edge of the valley and are extensively farmed. Approximately 17\% of the entire area of the Upper Nurzec River Valley is covered by forests. Coniferous forests predominate in this area, followed by mixed forests, while the smallest part is covered by deciduous forests. Woodland areas are small and disconnected from each other, with the exception of the large complex (more than $100 \mathrm{ha}$ ) located in the north-eastern part of the valley. The whole area is protected under Natura 2000 (Special Protection Areas: OSO Dolina Górnego Nurca PLB200004, protected area: $40 \mathrm{~km}^{2}$; Special Areas of Conservation: Ostoja w Dolinie Górnego Nurca PLH200021, protected area: 55 $\mathrm{km}^{2}$ ). Due to extensive farming in this region, more than 140 breeding bird species have been observed here (Wilk et al. 2010).

We randomly selected 54 recording locations further called as points within the study area based on an orthophoto map. Half of the points (27) were located in meadows and arable fields (open habitats), while the other 27 points were within forests (the distance from the point to the forest edge 
was greater than $100 \mathrm{~m}$ ). The distance between neighbouring survey points was greater than $500 \mathrm{~m}$, which minimised the probability of recording the same individuals at different points.

\section{Fieldwork}

At each point, an autonomous sound recorder (Song Meter SM3 Wildlife Acoustics with two built-in omnidirectional microphones; signal-to-noise ratio $68 \mathrm{~dB}$; we used 16 autonomous sound recorders) continuously collected data from one hour before dawn to 10:00 AM the next day once during the breeding season, from April 29th to May 6th, 2018. Thus, in each point we recorded two mornings and one night. Here, night was defined as the period from astronomical dusk to astronomical dawn. Astronomical dusk is the time when the geometrical center of the Sun falls 18 degrees below the horizon (in our study area and study period, this occurred between 10:24 and 10:52 PM). After this, the sky is no longer illuminated. Astronomical dawn occurs when the geometric center of the Sun rises 18 degrees below the horizon, and the sky is still absolutely dark (in our study area and study period, between 1:57 and 2:26 AM). Thus, in each point we analysed, on average, $4 \mathrm{~h}$ of nocturnal soundscape recordings.

To evaluate bird species richness in each recording point, we analysed morning recordings (from 4:02 AM to 7:57 AM) from two consecutive days. From each morning we randomly selected and analysed two 10-min recording sessions (separated by $5 \mathrm{~min}$ ). In total, in each point we analysed $40 \mathrm{~min}$ of daily recordings $(2 \times 10 \mathrm{~min} \times 2$ days $)$.

Depending on the condition of the habitat we placed recorders on trees or shrubs between 2 and $5 \mathrm{~m}$ above ground level. There was no strong wind or rain during the study period, meaning that the weather conditions were conducive to data collection.

\section{Acoustic analyses}

The autonomous sound recorders collected two-channel soundscape recordings ( $48 \mathrm{kHz} / 16-b i t$ sampling rate). Bioacoustics data were analysed using Avisoft SAS Lab Pro 5.2.12 software. To generate spectrograms, we used the parameters 1024 FFT Length, 75\% Frame, and Hamming Window. During manual scanning of the spectrograms, all recorded songs and calls were classified to species. Additionally, we noted the time (in seconds) of the beginning of each song. In our analyses we included all vocalisations (i.e., songs of songbirds and calls of non-songbirds) whose function seemed to be equivalent to that of songbirds' song- territory defence and mate attraction. Thus the songs of Skylarks as well as the calls of Lapwings were considered night vocalisations, but not the contact calls of Blackbirds.
To analyse the 10-min daytime recordings we also manually scanned the spectrograms. For each 10-min recording we prepared a list of recorded species. Certainly we did not detect all vocalizing species during the day, but we did not notice any typical daytime singing species that were not detected during the night.

When we had difficulties with species recognition, we compared unrecognised songs or calls with birdsong samples available on-line through the bioacoustics library of the Xeno-Canto Foundation.

\section{Statistical analyses}

As a first step we calculated the number of species detected in each point. We also determined which species were recorded only in the forests, only in the open areas, or in both type of habitats. Then we determined the intensity of singing at night by each species by calculating the mean with standard error for each species separately. In order to test the difference between mean species intensity of singing at night we used Kruskal-Wallis test (assumptions for ANOVA were violated). Temporal patterns in night-song activity of the most common species in the study site are presented as the graph with frequency of singing as y-axis and time during the night as $x$-axis. Additionally, we tested for differences in the number of diurnal species singing by night in forests and open habitat using a generalized linear model (GLM). We built a Poisson model (using a log-link function) with the number of species as a response variable, type of habitat as a fixed effect, and length of the night as well as number of species recorded during the day (both log-transformed) as an offset. Finally, we calculated the number of points at which a given species sang both during the day and at night. All statistical analyses were done in R software version 3.4.2 ( $\mathrm{R}$ core team 2017).

\section{Results}

During the study we recorded 88 bird species, representing 12 orders and 32 families (Online Appendix 1). One species was only recorded singing at night, 64 species sang only during the day, while 23 species vocalised both in the day and in the night. In total, we recorded 24 bird species singing at night (Table 1), representing 7 orders and 15 families (Fig. 1, Table 1). Eleven species were observed only at points located in open areas, three species were observed only at points located in forests, and seven species were observed in both types of habitat (Table 1). Finally, 83 of the species we identified were typically diurnal (excluding e.g. waterfowl), and 21 of these were recorded singing at night (6 orders and 13 families). The majority of the diurnal species that sang at night were songbirds (13 species). Three species 
Table 1 Bird species recorded singing during the night

\begin{tabular}{|c|c|c|c|c|c|}
\hline Species (English) & Species (Latin) & Family & Suborder & Order & Habitat \\
\hline Black-tailed godwit & Limosa limosa & Scolopacidae & Non-songbird & Charadriiformes & $\mathrm{O}$ \\
\hline Common crane & Grus grus & Gruidae & Non-songbird & Gruiformes & $\mathrm{O} / \mathrm{F}$ \\
\hline Common cuckoo & Cuculus canorus & Cuculidae & Non-songbird & Cuculiformes & $\mathrm{O} / \mathrm{F}$ \\
\hline Common grasshopper warbler & Locustella naevia & Locustellidae & Songbird & Passeriformes & $\mathrm{O} / \mathrm{F}$ \\
\hline Common moorhen & Gallinula chloropus & Rallidae & Non-songbird & Gruiformes & $\mathbf{O}$ \\
\hline Common reed bunting & Emberiza schoeniclus & Emberizidae & Songbird & Passeriformes & $\mathrm{O}$ \\
\hline Common snipe & Gallinago gallinago & Scolopacidae & Non-songbird & Charadriiformes & $\mathrm{O} / \mathrm{F}$ \\
\hline Common quil & Coturnix coturnix & Phasianidae & Non-songbird & Galliformes & $\mathrm{O} / \mathrm{F}$ \\
\hline Common whitethroat & Sylvia communis & Sylviidae & Songbird & Passeriformes & $\mathrm{O}$ \\
\hline Common wood pigeon & Columba palumbus & Columbidae & Non-songbird & Columbiformes & $\mathrm{F}$ \\
\hline Corn bunting & Emberiza calandra & Emberizidae & Songbird & Passeriformes & $\mathrm{O}$ \\
\hline Corncrake & Crex crex & Rallidae & Non-songbird & Gruiformes & $\mathbf{O} / \mathbf{F}$ \\
\hline Eurasian skylark & Alauda arvensis & Alaudidae & Songbird & Passeriformes & $\mathrm{O}$ \\
\hline Eurasian reed warbler & Acrocephalus scirpaceus & Acrocephalidae & Songbird & Passeriformes & $\mathrm{O}$ \\
\hline Eurasian wren & Troglodytes troglodytes & Troglodytidae & Songbird & Passeriformes & $\mathrm{F}$ \\
\hline Eurasian woodcock & Scolopax rusticola & Scolopacidae & Non-songbird & Charadriiformes & $\mathrm{O}$ \\
\hline Lesser whitethroat & Sylvia curruca & Sylviidae & Songbird & Passeriformes & $\mathrm{O}$ \\
\hline Marsh warbler & Acrocephalus palustris & Acrocephalidae & Songbird & Passeriformes & $\mathrm{O}$ \\
\hline Northern lapwing & Vanellus vanellus & Charadriidae & Non-songbird & Charadriiformes & $\mathrm{O} / \mathrm{F}$ \\
\hline Sedge warbler & Acrocephalus schoenobaenus & Acrocephalidae & Songbird & Passeriformes & $\mathrm{O}$ \\
\hline Thrush nightingale & Luscinia luscinia & Muscicapidae & Songbird & Passeriformes & $\mathrm{O} / \mathrm{F}$ \\
\hline Whinchat & Saxicola rubetra & Muscicapidae & Songbird & Passeriformes & $\mathrm{O}$ \\
\hline Whooper swan & Cygnus cygnus & Anatidae & Non-songbird & Anseriformes & $\mathbf{O}$ \\
\hline Woodlark & Lullula arborea & Alaudidae & Songbird & Passeriformes & $\mathrm{F}$ \\
\hline
\end{tabular}

Habitat: $\mathrm{O}-$ species recorded only in open habitats; $\mathrm{F}$ - species recorded only in forests; $\mathrm{O} / \mathrm{F}$ - species recorded both in open habitats and forests.

Bold letters indicate species excluded from statistical analyses

were excluded from statistical analyses: Common Moorhen (Gallinula chloropus), Corncrake, and Whooper Swan (Cygnus cygnus). Corncrakes are a nocturnally active species, which call intensively by night and occasionally by day. The Common Moorhen and Whooper Swan are waterfowl that do not breed in the Upper Nurzec River Valley because of a lack of appropriate habitats; they use this location only as a stopover point during migration.

\section{Intensity of night singing by species}

The average number of songs (number of songs per point) produced at night varied significantly among species (Kruskal-Wallis: $X^{2}=443.37 d f=20, p<0.001$; Fig. 2). The highest average number of songs was produced by the Thrush Nightingale (Luscinia luscinia; $x=1101.9$, $S D=1566.4$ ), Common Cuckoo (Cuculus canorus; $x=368.8, S D=615.5$ ), and Sedge Warbler (Acrocephalus schoenobaenus; $x=116.3, S D=400.4$ ). The species with the lowest average number of songs were the Common Wren (Troglodytes troglodytes; $x=0.02, S D=0.14$ ), Common
Whitethroat (Sylvia communis; $x=0.06, S D=0.30$ ), and Corn Bunting (Emberiza calandra; $x=0.04, S D=0.27$ ).

Additionally, we examined how often a given species sang in the same point both in the day and at night (Online Appendix 1, Appendix 2). The Common Grasshopper Warbler (Locustella naevia) almost always sang during both the day and night (94\% of points at which the species was recorded). Instead, the opposite pattern was found for the Eurasian Wren, which sang in both the day and night in only $10 \%$ of points.

\section{Temporal patterns of night-singing activity}

Temporal patterns of night-singing activity by diurnal birds varied among species (Fig. 3). Some species sang almost continuously all night long (e.g., Thrush Nightingale, Common Grasshopper Warbler, Sedge Warbler), while others had clear peaks of vocal activity (e.g., Common Quail, Coturnix coturnix; Common Snipe, Gallinago gallinago; Common Crane, Grus grus). For example, the nocturnal vocal activity 


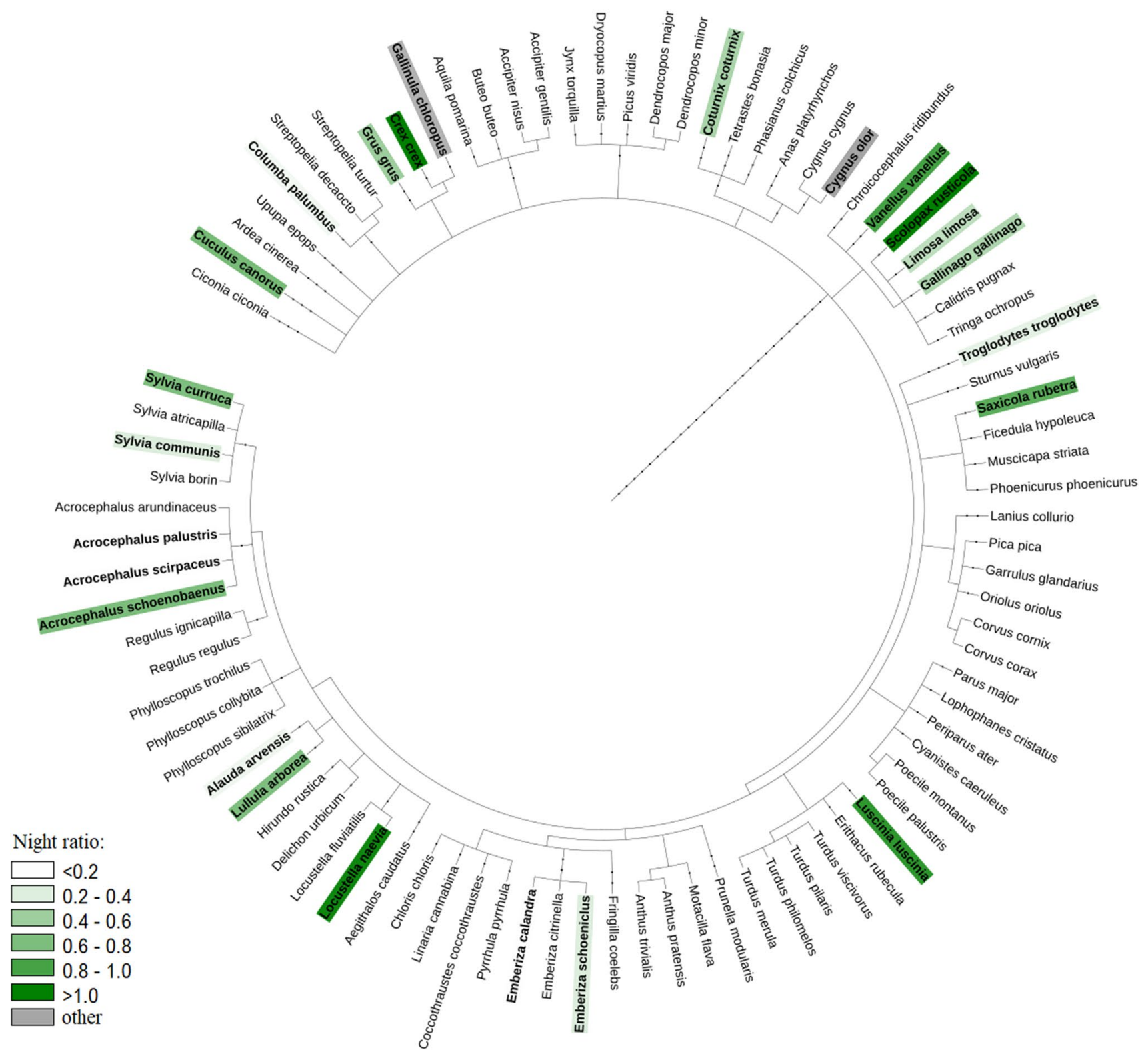

Fig. 1 Phylogenetic tree of species detected in our study. Bold letters and colorful frames indicate species in which night singing was recorded. Night ratio- the number of points at which a given species

of Thrush Nightingales fluctuated around a fixed level most of the night, then dropped drastically about an hour before astronomical dawn. Instead, the peak in the nocturnal singing activity of Whinchats (Saxicola rubetra) occurred approximately one hour before dawn, with a gradual rise before and a gradual fall after. was detected at night divided by the number of points at which the species was detected during both the day and the night. In the legend " $>1.0$ " indicates typically nocturnal species of birds

\section{Comparison of nocturnal singing between habitats}

The GLM revealed that more species sang at night in open areas than in forests $\left(X^{2}=12.141, d f=1, p<0.001\right.$; Fig. 4 , Table 2). The average number of diurnal bird species singing at night per point in the forest was two, while in open areas this rose to five. 


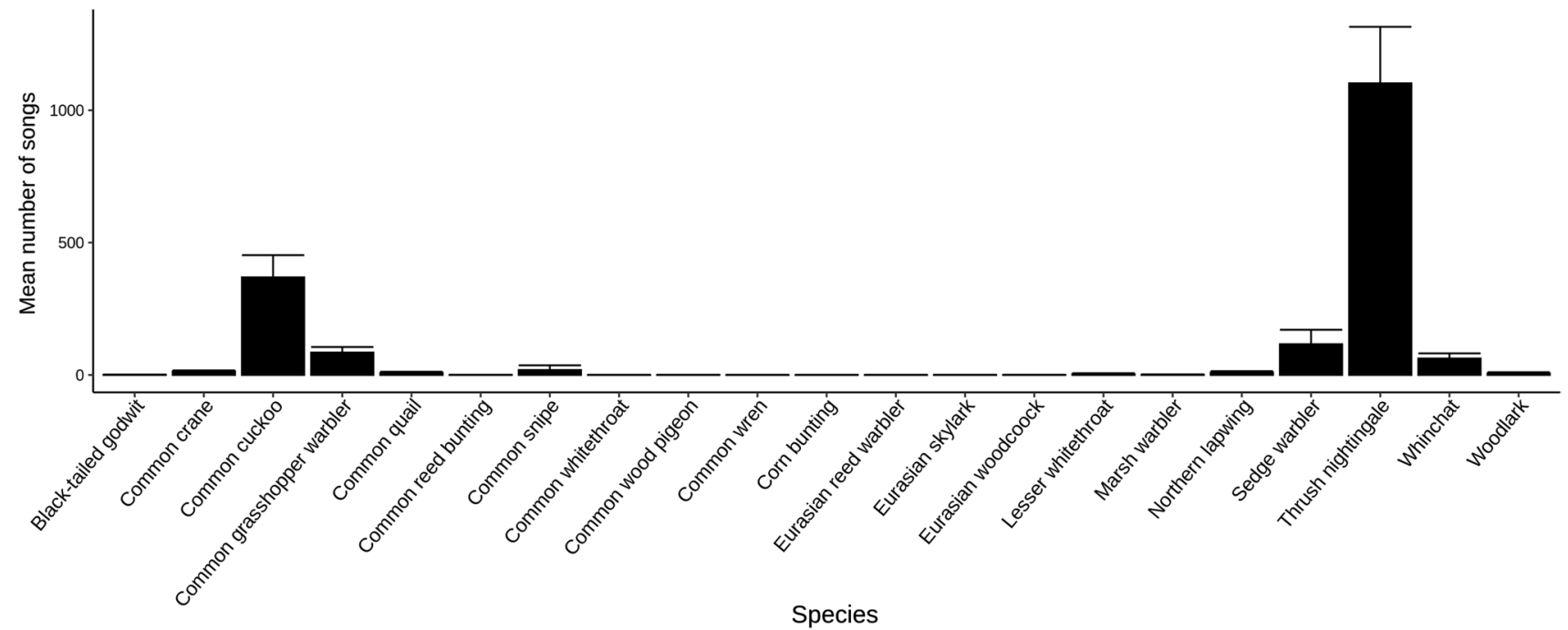

Fig. 2 Average intensity (number of songs/number of all points) of singing at night across species in forests and open areas ( $N=54$ points). Whiskers represent standard error of the mean
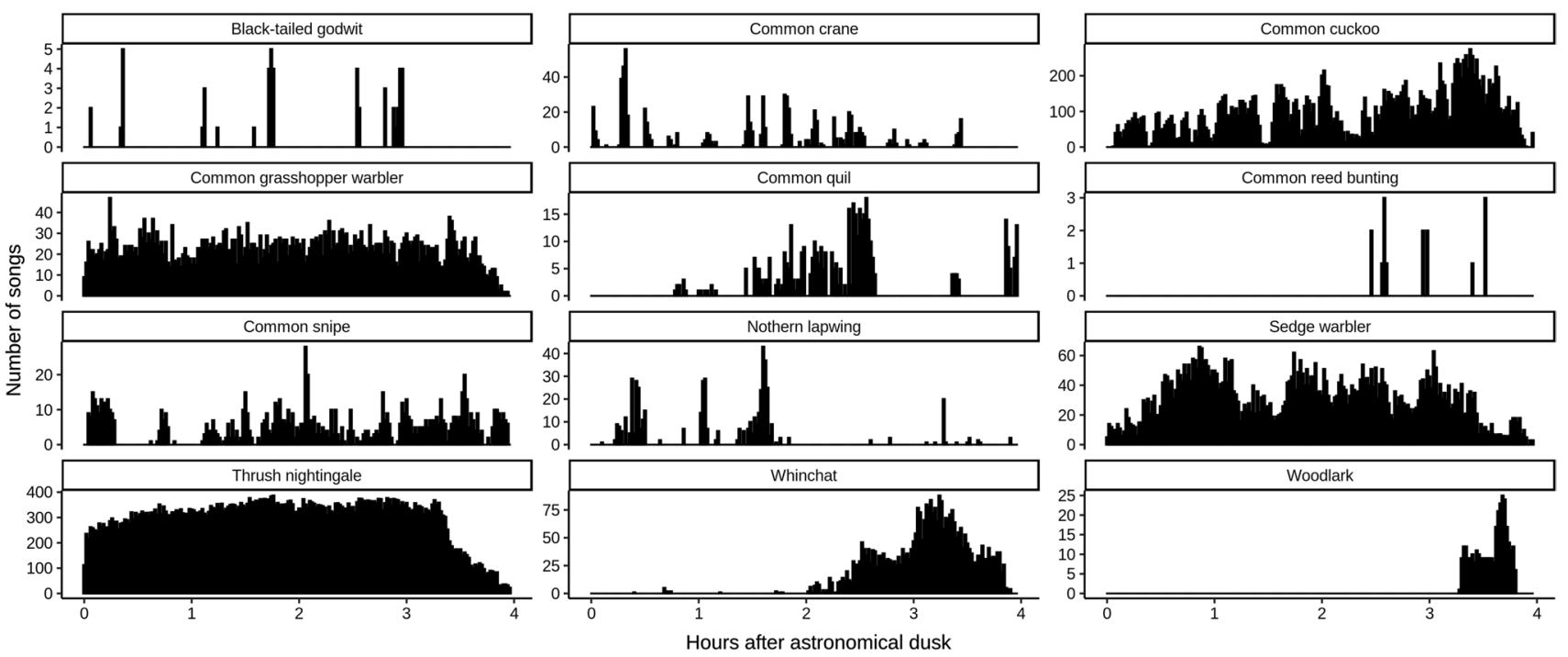

Fig. 3 Temporal night-singing activity of selected species. 0 on the $x$-axis indicates astronomical dusk. The bars represent the total number of songs from all points

\section{Discussion}

The results of this study revealed that nocturnal singing by diurnal birds in central Europe is quite common. Of the 83 diurnal species recorded, 21 were found to sing at night (25.3\%; Fig. 1). This proportion was similar to values reported for North America (La 2012), which may suggest that this is a general pattern among temperate regions, where a considerable number of diurnal birds sing also at night. Nocturnal singing in diurnal birds was common in multiple families, which were often genetically distinct (e.g., Gruiformes, Alaudidae, Scolopacidae), while in other families this behaviour was not detected (e.g., Laniidae, Paridae, Motacillidae). This suggests that night singing by diurnal birds might have evolved independently several times. The frequency and intensity of night singing in our study varied across species (Figs. 2, 3). We found species that sang at night only occasionally, producing only a few songs (e.g., Common Wren, Common Whitethroat, or Corn Bunting), those that sang regularly but not intensively (e.g., Common Snipe, Common Grasshopper Warbler), and those that sang regularly and very intensively (e.g., Thrush Nightingale, Common Cuckoo; Fig. 2). Similar patterns of species-specificity were also reported from North America (La 2012). 


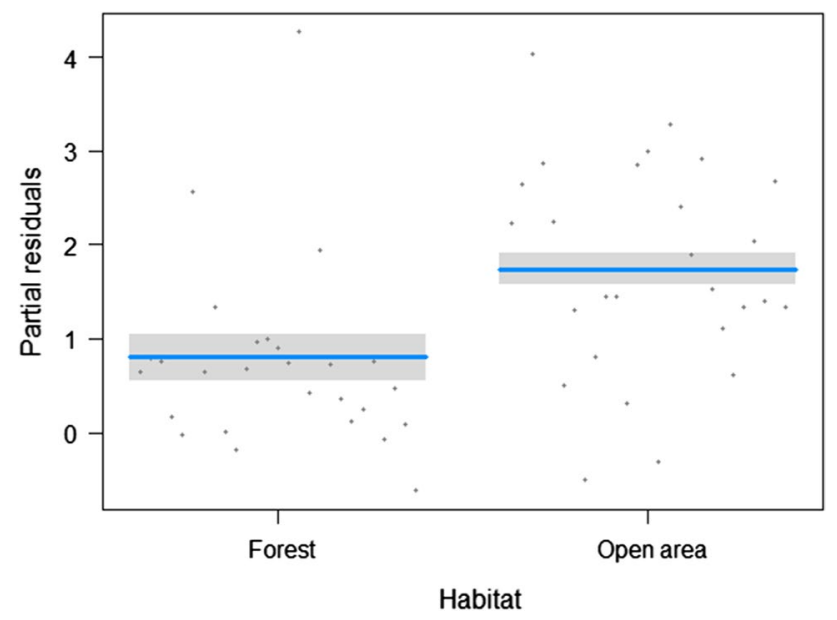

Fig. 4 The number of species singing at night in two types of habitat: forests and open areas. Graph shows model estimates including two offset. Blue line: the expected value. Gray band: the 95\%-confidence interval for the expected value. Dark gray dots: partial residuals (color figure online)

Table 2 Results of GLM, showing the differences in number of detected species between open and forest areas

\begin{tabular}{lrlrr}
\hline & Estimate & Std. error & \multicolumn{1}{l}{ zvalue } & $P$-value \\
\hline Intercept & -2.7111 & 0.1270 & -21.347 & $<0.001$ \\
Habitat-open area & 0.9741 & 0.1521 & 6.406 & $<0.001$ \\
\hline
\end{tabular}

Taken together, this diversity in behavioural patterns may indicate that the functions of night singing by diurnal birds are likewise varied. Furthermore, the function of night singing may change across the breeding season. In the Field Sparrow (Spizella pusilla), a species which has both simple and complex songs in its repertoire, the frequency of simple vocalisations decreases as the breeding season progresses, while complex songs appear more often. The highest degree of song complexity is found during the period of highest reproductive activity. This suggests that simple vocalisations are used to communicate to other males in order to defend the territory, while complex song performs the function of attracting females (Celis-Murrilo et al. 2016). In the Common Nightingale (Luscinia megarhynchos), unpaired males sing intensely at night (Armhein et al. in 2002). This activity becomes intermittent after pairing, but is activated again when a male loses his mate, which suggests that the function of nocturnal singing in this species is attraction of a female. In the Yellow-breasted Chat (Icteria virens), males are more likely to leave their territories and seek females (extra-pair copulations) when their female mates are in a non-fertile phase. On the other hand, during the most fertile period, males show high nocturnal vocal activity, probably to prevent extra-pair copulations by their mates (Ward et al. 2014). Another species, the Ovenbird, does not respond aggressively to the night song of foreign males, which also suggests that night singing in this species is used for mate attraction rather than territory defence (Foote et al. 2018b). Nocturnal singing can be also explained as a strategy for reducing acoustic interference in areas that are noisy during the day, as was shown for urban populations of European Robins (Erithacus rubecula; Fuller et al. 2007).

It is interesting that, in our location, night singing by diurnal birds was strongly limited to the species that inhabited open environments. For some of these, our study may be the first report of nocturnal singing activity (e.g., Common Whitethroat; Lesser Whitethroat, Sylvia curruca; Whinchat; Northern Lapwing, Vanellus vanellus). Of the species that typically inhabit forests, we found night singing in only three: Common Wood Pigeon, Eurasian Wren, and Woodlark. Thus, the question is: does better lighting at night in open habitats induce night singing, or are there other ecological factors in the forest that limit night singing? The Upper Nurzec River Valley is not polluted by artificial light, so this factor does not contribute to nocturnal vocal activity here (Miller 2006; Nordt and Klenke 2013; Da Silva and Kempenaers 2017). However, in open habitats there is more natural light at night than in dense forests. This may explain why birds sing more often at night in open habitats than in the forest-even a small increase in light levels in open habitats may be enough to induce singing. Alternatively, the risks from nocturnal predators (e.g., owls or small predacious mammals) may be higher in forests, and birds reduce their predation risk by staying silent at night. Such behaviour was observed in the Veery (Catharus fuscescens), in which birds sang less intensely at dusk when voices of owls were played back to simulate strong predator pressure (Schmidt and Belinsky 2013).

Our current understanding of the mechanism and function of night singing by diurnal birds is further constrained by variations in the definition of night used in different studies. Depending on the study in question, night can be defined as the period between civil, nautical, or astronomical dusk and dawn. Depending on the definition chosen, the period of time that is analysed can be quite different from one study to another, incorporating (or not) significant variations in lighting conditions, especially at the beginning and the end of the night period. By defining night as the period between civil dusk and dawn, one study may include the beginning of the dawn chorus and the end of the dusk chorus, while a study that uses astronomical dusk and dawn will exclude this activity. Such inconsistency among studies drastically changes both the number of species identified as night singers as well as the intensity of night singing, defined as the number of songs produced by an individual per night. In our study we applied the strictest definition of night: the period 
between astronomical dusk and dawn, when the sky is not illuminated by the sun. Another challenge arises from the analysis of the intensity of night singing. Bird song varies in duration and complexity across taxa (Catchpole and Slater 2003). Some species have extremely long, continuous songs that may even be up to a few minutes long (e.g., Common Grasshopper Warbler), while vocalisations of other species (e.g., Common Cuckoo) are very short and last just a few seconds. Thus, defining night-singing activity as the number of songs produced by an individual (as used here) produces only an approximation of the time that individuals spend vocalising at night.

In conclusion, our study showed that approximately $25 \%$ of diurnal bird species in a temperate region of central Europe also sing at night. Night singing was quite widespread across bird taxa (observed in 24 species, belonging to 7 orders and 15 families), which suggests that this behaviour evolved independently in different groups of birds. Night singers, based on the frequency and intensity of singing, could be classified as singing occasionally, regularly but not intensively, or regularly and intensively. Night singing occurred more often in open habitats than in forests, which could be explained by differences in light levels or in the presence/activity of nocturnal predators. At a basic level, nocturnal singing in diurnal birds seems to be limited by the availability of light, but other environmental factors may serve as additional constraints on night-time activity.

Acknowledgements We thank Lindsay Higgins for language correction and helpful comments on the manuscript.

Funding Study partly financed from budget funds for science in the years 2019-2020 as a research project under the "Diamond Grant" program (0128/DIA/2019/48).

Data availability The dataset generated during this study are included in this published article [and its supplementary information files].

\section{Compliance with ethical standards}

Conflicts of interest The authors declare that they have no conflict of interest.

Ethical approval In our study we did not conduct experiments with animals, therefore we did not need any special permissions. Access to our study area is not restricted in any way. According with Polish law, access to public and private-owners' lands (including forests and agricultural areas) is not restricted, excluding fence areas or areas where is no entry. Most of the survey points were located on public areas, we did not meet lands to which accessibility was limited or illicit. No specific permissions were required for conducting our study. The study did not involve endangered or protected species.

Open Access This article is licensed under a Creative Commons Attribution 4.0 International License, which permits use, sharing, adaptation, distribution and reproduction in any medium or format, as long as you give appropriate credit to the original author(s) and the source, provide a link to the Creative Commons licence, and indicate if changes were made. The images or other third party material in this article are included in the article's Creative Commons licence, unless indicated otherwise in a credit line to the material. If material is not included in the article's Creative Commons licence and your intended use is not permitted by statutory regulation or exceeds the permitted use, you will need to obtain permission directly from the copyright holder. To view a copy of this licence, visit http://creativecommons.org/licenses/by/4.0/.

\section{References}

Alessi MG (2010) The nocturnal behaviors of yellow-breasted chats. Thesis. IDEALS. https://www.ideals.illinois.edu/handl e/2142/16144

Amrhein V, Korner P, Naguib M (2002) Nocturnal and diurnal singing activity in the nightingale: correlations with mating status and breeding cycle. Anim Behav 64:939-944

Barclay RM, Leonard ML, Friesen G (1985) Nocturnal singing by marsh wrens. Condor 87:418-422

Bowmaker JK, Martin GR (1978) Visual pigments and colour vision in a nocturnal bird, Strix aluco (Tawny owl). Vis Res 18(9):1125-1130

Bradbury JW, Vehrencamp SL (1998) Principles of animal communication. Sinauer Associates, Sunderland, MA

Catchpole CK, Slater PJ (2003) Bird song: biological themes and variations. Cambridge University Press, Cambridge

Celis-Murillo A, Stodola KW, Pappadopoli B, Burton JM, Ward MP (2016) Seasonal and daily patterns of nocturnal singing in the Field Sparrow (Spizella pusilla). J Ornithol 157:853-860

Da Silva A, Valcu M, Kempenaers B (2016) Behavioural plasticity in the onset of dawn song under intermittent experimental night lighting. Anim Behav 117:155-165

Da Silva A, Kempenaers B (2017) Singing from North to South: latitudinal variation in timing of dawn singing under natural and artificial light conditions. J Anim Ecol 86:1286-1297

Edson JM (1893) Birds that sing at night. Science 22:221-222

Ehnes M, Dech JP, Foote JR (2018) Seasonal changes in acoustic detection of forest birds. J Ecoacoust 2:\#QVDZO7

Foote JR, Nanni LK, Schroeder R (2018) Seasonal patterns of nocturnal singing by ovenbirds and white-throated sparrows. Behaviour 154:1275-1295

Foote JR, Marini KL, AL-Ani H, (2018) Understanding the function of nocturnal song in ovenbirds: males do not countersing at night. J Avian Biol 49:012511

Fuller RA, Warren PH, Gaston KJ (2007) Daytime noise predicts nocturnal singing in urban robins. Biol Lett 3:368-370

Henwood K, Fabrick A (1979) A quantitative analysis of the dawn chorus: temporal selection for communicatory optimization. Am Nat 114:260-274

King B (1966) Nocturnal singing and feeding by Robins in winter. $\mathrm{Br}$ Birds 59:501-502

Krebs JR, Kacelnik A (1983) The dawn chorus in the great tit (Parus major): proximate and ultimate causes. Behaviour 83:287-308

Kroodsma DE, Byers BE (1991) The function (s) of bird song. Am Zool 31:318-328

Kumar A (2003) Acoustic communication in birds. Resonance $8(6): 44-55$

La VT (2012) Diurnal and nocturnal birds vocalize at night: a review. Condor 114:245-257

Lampe HM, Espmark YO (1994) Song structure reflects male quality in pied flycatchers Ficedula hypoleuca. Anim Behav 47:869-876

McNeil R, McSween A, Lachapelle P (2005) Comparison of the retinal structure and function in four bird species as a function of the time they start singing in the morning. Brain Behav Evol 65:202-214 
Mendes S, Colino-Rabanal VJ, Peris SJ (2011) Bird song variations along an urban gradient: the case of the European blackbird (Turdus merula). Landsc Urban Plan 99:51-57

Miller MW (2006) Apparent effects of light pollution on singing behavior of American robins. The Condor 108:130-139

Mountjoy DJ, Lemon RE (1991) Song as an attractant for male and female European starlings, and the influence of song complexity on their response. Behav Ecol Sociobiol 28:97-100

Nordt A, Klenke R (2013) Sleepless in town-drivers of the temporal shift in dawn song in urban European blackbirds. PLoS ONE 8:e71476

Pierce FJ (1922) A midnight singing catbird. Wilson Bull 34:186

R Core Team (2017) R: A language and environment for statistical computing. R Foundation for Statistical Computing, Vienna, Austria. https://www.R-project.org/

Russell HN (1916) On the albedo of the planets and their satellites. Proc Natl Acad Sci 2:74-77

Schmidt KA, Belinsky KL (2013) Voices in the dark: predation risk by owls influences dusk singing in a diurnal passerine. Behav Ecol Sociobiol 67:1837-1843

Staicer CA, Spector DA, Horn AG (1996) The dawn chorus and other diel patterns in acoustic signaling. In: Kroodsma DE, Miller EH (eds) Ecology and evolution of acoustic communication in birds. Comstock Publishing Associates, Cornell Univeristy Press, USA, pp 426-453

Stevenson A (1893) A night-singing catbird. Science 21:346
Thomas RJ, Széskely T, Cuthill IC, Harper DG, Newson SE, Frayling TD, Wallis PD (2002) Eye size in birds and the timing of song at dawn. Proc R Soc Lond B Biol Sci 269:831-837

Thomas RJ, Drewitt EJ, Kelly DJ, Marples NM, Semple S (2003) Nocturnal playbacks reveal hidden differences in singing behaviour between populations of Robin Erithacus rubecula. Bird Study 50:84-87

Tyler GA, Green RE (1996) The incidence of nocturnal song by male Corncrakes Crex crex is reduced during pairing. Bird Study 43:214-219

Ward MP, Alessi M, Benson TJ, Chiavacci SJ (2014) The active nightlife of diurnal birds: extraterritorial forays and nocturnal activity patterns. Anim Behav 88:175-184

Wilk T, Jujka M, Krogulec J, Chylarecki P (2010) Important bird areas of international importance in Poland. OTOP, Marki

Wright HW (1913) Morning awakening and even-song: second paper. Auk 30:512-537

York JE, Young AJ, Radford AN (2014) Singing in the moonlight: dawn song performance of a diurnal bird varies with lunar phase. Biol Lett 10:20130970

Publisher's Note Springer Nature remains neutral with regard to jurisdictional claims in published maps and institutional affiliations. 